\title{
Ефективність ретиналаміну та методів його застосування в лікуванні діабетичної ретинопатії
}

\author{
N. K. HREBEN
}

National Medical University by O. O. Bohomolets

\author{
RETINALAMIN EFFICIENCY AND METHODS OF ITS USE IN THE TREATMENT OF DIABETIC \\ RETINOPATHY
}

\begin{abstract}
В останні роки ведеться інтенсивний науковий пошук, спрямований на пізнання різних ланок складного патогенезу діабетичної ретинопатії (ДР) та методів лікування останньої. Робота присвячена вивченню ефективності застосування ретиналаміну в лікуванні пацієнтів з ДР. Проводили обстеження та лікування пацієнтів із препроліферативною та проліферативною ДР у двох клінічних групах. У І групі пацієнтам вводили ретиналамін у дозі 5,0 мг щоденно 10 днів, у II групі хворим вводили 1,0 мл ретиналаміну в дозі 5,0 мг одноразово в теноновий простір. У результаті лікування спостерігали покращання показників КЧЗМ та ЛЗА в обох групах лікування, ПЕЧФ, ЛЗА значно виразніше у ІІ групі дослідження. На фоні лікування ретиналаміном у пацієнтів обох груп відмічали зменшення товщі сітківки, особливо макулярний набряк зменшувався у II групі пацієнтів при введенні препарату в субтеноновий простір. Визначено позитивні тенденції: підвищення гостроти зору на 0,05-0,2 \% та функціональної активності сітківки у 68 \% пацієнтів свідчить про ефективність препарату, особливо при його введенні в субтеноновий простір ока.

An intensive scientific search is conducted in recent year dedicated to cognition of different links of difficult pathogenesis of diabetic retinopathy (DR), and the methods of its treatment. The work is devoted to the study of efficiency of application of retinalamine in the treatment of patients with DR. An inspection and treatment of patients were conducted with preproliferative and proliferative DR, in two clinical groups. In the first group retinalamine was entered to the patients in a dose of $5.0 \mathrm{mg}$ every day during 10 days, in the second group $-1.0 \mathrm{ml}$ of retinalamine was entered to the patients in a dose of $5.0 \mathrm{mg}$ singly in subconjunctiveal space. As a result there was an improvement of indexes of electrophysiological parameters in both groups of treatment, lability of optic nerve considerably more distinctly in the II research group. On the background of treatment with retinalamine for the patients of both groups the reduction was marked by decreasement of retinas especially macular oedema diminished in the II group of patients when injected drug in subconjunctiveal space. Positive trends were determined: visual acuity at $0.05-0.2 \%$ and functional activity of the retina in $68 \%$ of patients demonstrate efficacy, especially when it is injected into the subconjunctiveal space of an eye.
\end{abstract}

Постановка проблеми і аналіз останніх досліджень та публікацій. Діабетична ретинопатія (ДР) - одне з найбільш тяжких ускладнень цукрового діабету (ЦД), що часто приводить до розвитку сліпоти, в тому числі в осіб молодого та працездатного віку. В останні роки ведеться інтенсивний науковий пошук, спрямований на пізнання різних ланок складного патогенезу ДР $[1,5,6,7]$. Одним із факторів розвитку та прогресування захворювання $\epsilon$ порушення регуляції переносу інформаційних молекул між клітинами тканин. Тому посилення синтезу регуляторних пептидів у самому організмі або шляхом введення лікарських засобів на основі пептидних препаратів (цитомединів) призводить до зниження інтенсивності патологічного процесу,сприяєвідновленнютазбереженнюрегуляторних механізмів міжклітинної взаємодії [2, 3, 4]. Таким чином, патогенетична обгрунтованість біорегулюючої терапії дозволила їй отримати широке розповсюдження в офтальмології, а саме при лікуванні пацієнтів 3 ДР $[2,3,5]$.

Мета роботи: вивчення ефективності застосування ретиналаміну в лікуванні пацієнтів з ДР на основі комплексу клініко-функціональних методів дослідження та визначення найбільш ефективного методу застосування препарату.

Матеріали і методи. У роботі надано результати лікування ретиналаміном 43 пацієнтів (79 очей) 3 препроліферативною та проліферативною ДР (18 чоловіків та 25 жінок) у віці від 23 до 78 років (середній вік $(56,3 \pm 12,9)$ року). Для оцінки дослідження хворі поділялись на дві групи: I група - 25 пацієнтів (50 очей), II група - 18 пацієнтів (29 очей). Серед пацієнтів, яких обстежували, I тип ЦД 
діагностовано у 15 осіб, II тип ЦД - у 28 осіб. Середня тривалість ЦД складала $(15,9 \pm 5,7)$ року.

Всім пацієнтам до та після обстеження, крім стандартного офтальмологічного дослідження, проводили електрофізіологічні дослідження, кольорову фотографію, флюоресцентну ангіографію очного дна та оптичну когерентну томографію. У І групі пацієнтам вводили ретиналамін у дозі 5,0 мг щоденно 10 днів, у II групі пацієнтам вводили 1,0 мл ретиналаміну в дозі 5,0 мг однократно в теноновий простір.

Методика операції. Під місцевою триразовою краплинною анестезією розчину алкаїну 0,5 \% проводили розтин кон'юнктиви в нижньо-зовнішньому квадранті, в 5 мм від лімбу, в цій ділянці виконували розтин тенонової оболонки. Шпателем формували карман в теноновому просторі до зорового нерва. В карман вводили тупокінцеву канюлю. На розтин накладали кисетний шов. Через канюлю вводили ретиналамін, одночасно з цим затягували кисетний шов (методика I. Б. Максимова) [2, 3].

Результати досліджень та ̈х обговорення. На фоні застосування в терапії пацієнтів з ДР ретиналаміну

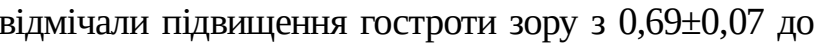
$0,78 \pm 0,05$. Гострота зору підвищувалась на $0,05-0,2$ у 73 \% пацієнтів. Отримані результати в більшості випадків були збережені від 3 до 7 місяців після лікування. Динаміка показників гостроти зору та поля зору наведена в таблиці 1.

Таблиця 1. Динаміка середніх клініко-фрункціональних показників залежно від способу лікування

\begin{tabular}{||c|c|c|c||}
\hline \hline Група & & Середня гострота зору & Поле зору на білий колір (град) \\
\hline \multirow{2}{*}{ До лікування } & I & $0,54 \pm 0,08$ & $425 \pm 8$ \\
\cline { 2 - 4 } & II & $0,62 \pm 0,07$ & $445 \pm 9$ \\
\hline Після лікування & I & $0,72 \pm 0,05$ & $465 \pm 6$ \\
\cline { 2 - 4 } & II & $0,76 \pm 0,1^{*}$ & $475 \pm 8^{*}$ \\
\hline
\end{tabular}

Примітка. * - достовірність різниці показників до та після лікування при р<0,05.

Для об’єктивної оцінки функціональної здатності активності сітківки проводили електрофізіологічні дослідження, які включали визначення порогу електричної чутливості за фосфеном (ПЕЧФ), кількісну частоту злиття мерехтінь (КЧЗМ), лабільність зорового аналізатора (ЛЗА) (табл. 2).

У результаті лікування спостерігали поліпшення показників КЧЗМ та ЛЗА в обох групах лікування, що свідчить про покращання трофічних процесів у сітківці та зоровому нерві. Важливо зазначити, що у II групі хворих ПЕЧФ у середньому підвищувався на $(83,0 \pm 1,5)$ мкА, а у I групі на $(65,5 \pm 1,7)$ мкА, а показники ЛЗА значно покращились на $(4,1 \pm 2,5)$ Гц у II групі, на $(2,3 \pm 1,7)$ Гц у - I групі. Покращання ПЕЧФ значно виразніше у II групі дослідження, що можна пояснити зменшенням набряку та протекторними властивостями ретиналаміну, а також більшою чутливістю фоторецепторів до лікування, що проводиться. А підвищення показників ЛЗА свідчить про зменшення ішемічних проявів у системі зорового нерва при оптиконейропатії, яка викликана ЦД.

Порівняльний аналіз ангіографічної картини очногоднадо тапісля лікуванняпроведено у22пацієнтів
(44 ока). На фоні терапії ретиналаміном відмічали зменшення дифузії барвника з мікроаневризмами, що свідчить про позитивний вплив препарату на стан внутрішнього гематоретинального бар'єра. Отримані спостереження збігаються з даними літератури про значний протекторний ефект ретиналаміну відносно судинного ендотелію [2, 3].

Клінічним доказом зменшення проникності судинної стінки на фоні приймання препарату $\epsilon$ часткова резорбція ліпідних ексудатів, зменшення ретинального набряку та кількості ретинальних геморагій. Останні факти знаходять підтримку в літературі про здатність ретиналаміну покращувати функціональний стан пігментного епітелію сітківки (ПЕС) та зовнішніх сегментів фоторецепторів, посилювати активність ретинальних макрофагів [3, 4, 5].

Для підтвердження позитивного впливу ретиналаміну на стан внутрішнього (ендотеліальні клітини, перицити) та зовнішнього (ПЕС) гематоретинального бар’єра проведено аналіз результатів лікування 18 пацієнтів із фокальним діабетичним макулярним набряком (МН). У ролі контрольного дослідження для об’єктивної кількісної оцінки МН проведено оптич-

Таблиця 2. Динаміка електрофізіологічних показників у хворих з ДР залежно від способу лікування

\begin{tabular}{||c|c|c|c|c||}
\hline \hline Група & & ПЕЧФ, мкА & КЧЗМ, ГЦ & ЛЗА, Гц \\
\hline \multirow{2}{*}{ До лікування } & I & $250,5 \pm 3,8$ & $34,5 \pm 2,8$ & $40,5 \pm 2,8$ \\
\cline { 1 - 5 } & II & $260,1 \pm 3,7$ & $36,1 \pm 2,5$ & $45,5 \pm 3,0$ \\
\hline \multirow{2}{*}{ Після лікування } & I & $185,0 \pm 1,6 *$ & $36,8 \pm 2,1^{*}$ & $42,8 \pm 2,4^{*}$ \\
\cline { 2 - 5 } & II & $177,1 \pm 1,6^{*}$ & $37,5 \pm 1,3^{*}$ & $49,6 \pm 2,3^{*}$ \\
\hline
\end{tabular}

Примітка. * - достовірність різниці показників до та після лікування при $\mathrm{p}<0,05$. 
ну когерентну томографію (ОКТ). На фоні лікування ретиналаміном у пацієнтів обох груп відмічали зменшення товщі сітківки, особливо МН зменшувався у II групі пацієнтів при введенні в субтеноновий простір та ефект тримався досить довго, однак різниця показників до та після лікування не була достовірною (табл. 3). Визначені позитивні тенденції зменшення МН свідчать про ефективність препарату та підтверджують припущення про вплив ретиналаміну на зовнішній та внутрішній гематоретинальний бар’єри.

Таблиця 3. Динаміка середніх значень товщі сітківки в центрі макули

\begin{tabular}{|c|c|c|c||}
\hline \hline Група & До лікування & Після лікування & Через 1 місяць \\
\hline I & $450 \pm 23$ & $413 \pm 19$ & $419 \pm 18$ \\
\hline II & $451 \pm 25$ & $404 \pm 23$ & $407 \pm 21$ \\
\hline
\end{tabular}

Динамічне спостереження за розвитком ДР після курсу лікування ретиналаміном близько 6-10 місяців виявило стабілізацію утворення мікроаневризм, венозних деформацій, площі ішемічних зон у ділянці заднього полюса та на периферії очного дна у більшості пацієнтів. Також слід зазначити про тенденцію до зменшення ексудативно-геморагічної активності в хоріоретинальному комплексі ока в даній групі хворих.

Висновки. 1. Виявлено позитивний вплив терапії 3 використанням ретиналаміну на зорові функції, електрогенез сітківки, що підтверджує підвищення гостроти зору на 0,05-0,2 \% та функціональної активності сітківки у 68 \% пацієнтів із ДР.

2. Виявлено позитивний вплив ретиналаміну на стан зовнішнього та внутрішнього гематоретинальних бар’єрів. Отримані результати флюоресцентної ангіографії судин сітківки та оптичної когерентної томографії підтверджують протективний ефект препарату на судинний ендотелій та пігментний епітелій сітківки.

3. Доведено ефективність застосування ретиналаміну в пацієнтів при введенні в субтеноновий простір. При цьому методі лікування найбільш виражене зменшення товщі сітківки та покращання електрофізіологічних показників (ПЕЧФ, ЛЗА).

\section{СПИСОК ЛІТЕРАТУРИ}

1. Дедов И. И. Сахарный диабет: ретинопатия, нефропатия / И. И. Дедов, М. В. Шестакова, Т. М. Миленькая. - М. : Медицина, 2001. - 175 с. - (Серия "Библиотека практикующего врача ) .

2. Максимов И. Б. Применение препарата ретиналамин в офтальмологии : пособие для врачей / И. Б. Максимов, В. В. Нероев, В. Н. Алексеев. - СПб., 2003. - 20 с.

3. Максимов И. Б. Ретиналамин в комплексном лечении инволюционных центральних дистрофий / И. Б. Максимов, Л. К. Мошетова, С. А. Савостьянова. - СПб., 2006. - 96 с.

4. Шестакова М. В. Блокада ренин-ангиотензиновой системы в профилактике и лечении диабетической ретинопатии: результаты исследования DIRECT [Режим доступа] / M. В. Шестако-

ва, М. Ш. Шамхалова // Consilium Medicum. - 2008. - Т. 10, № 9 - Режим доступа : (http://www.consilium-medicum.com/ magazines/cm/medicum/article/16023)

5. Antonetti D. A. Diabetic Retinopathy / D. A. Antonetti, R. Klein, T. W. Gardner // Engl. J. Med. - 2012. - 366. - P. 1227-1239.

6. A prospective randomized trial of intravitreal bevacizumab or laser therapy in the management of diabetic macular edema (BOLT study) 12-month data: report 2 / M. Michaelides, A. Kaines, R. D. Hamilton [et al.] // Ophthalmology. - 2010. - 117(6). - P. 1078-1086.

7. A Role for Omega-3 Polyunsaturated Fatty Acid Supplements in Diabetic Neuropathy / P. Yee, A. E. Weymouth, E. L. Fletcher, A. J. Vingrys // Inves. Ophthalmol. Vis. Sci. - 2010. - Vol. 51(3). P. $1755-1764$. 